\title{
Long-term survival and interruption of HAART in HIV-related pulmonary hypertension
}

\author{
Zinkernagel, A S ; von Overbeck, J ; Opravil, M ; Jenni, R ; Speich, R ; Mueller, N J
}

\begin{abstract}
Reported here is a case of a patient with pulmonary arterial hypertension related to HIV (PAHRH) in which lipodystrophy necessitated interruption of highly active antiretroviral therapy (HAART) and long-term survival was the outcome. Although previous studies have suggested antiretroviral therapy may benefit patients with this rare complication of HIV infection, no worsening of PAHRH was observed when HAART was interrupted. Clinical and echocardiographic parameters remained stable during 7 months of follow up. In cases in which HAART is associated with relevant toxicity, interruption of HAART in patients with PAHRH can be considered, but should be used only if no alternatives are available. Close follow-up is warranted.
\end{abstract}

DOI: https://doi.org/10.1007/s10096-005-1289-7

Posted at the Zurich Open Repository and Archive, University of Zurich

ZORA URL: https://doi.org/10.5167/uzh-75168

Journal Article

Published Version

Originally published at:

Zinkernagel, A S; von Overbeck, J; Opravil, M; Jenni, R; Speich, R; Mueller, N J (2005). Long-term survival and interruption of HAART in HIV-related pulmonary hypertension. European Journal of Clinical Microbiology Infectious Diseases, 24(2):153-155.

DOI: https://doi.org/10.1007/s10096-005-1289-7 


\section{Long-term survival and interruption of HAART in HIV-related pulmonary hypertension}

Published online: 12 February 2005

(C) Springer-Verlag 2005

\begin{abstract}
Reported here is a case of a patient with pulmonary arterial hypertension related to HIV (PAHRH) in which lipodystrophy necessitated interruption of highly active antiretroviral therapy (HAART) and long-term survival was the outcome. Although previous studies have suggested antiretroviral therapy may benefit patients with this rare complication of HIV infection, no worsening of PAHRH was observed when HAART was interrupted. Clinical and echocardiographic parameters remained stable during 7 months of follow up. In cases in which HAART is associated with relevant toxicity, interruption of HAART in patients with PAHRH can be considered, but should be used only if no alternatives are available. Close follow-up is warranted.
\end{abstract}

\section{Introduction}

HIV-infected individuals have a $0.5 \%$ incidence of pulmonary arterial hypertension, compared to $0.02 \%$ in the non-HIV-infected population $[1,2]$. Prognosis is poor, with a median survival period of 6 months, and treatment options are limited. In prospective studies of patients with

\author{
A. S. Zinkernagel · J. von Overbeck · M. Opravil · \\ N. J. Mueller $(\triangle)$ \\ Division of Infectious Diseases, Department of Medicine, \\ University Hospital, RAE U 74, \\ Rämistrasse 100, \\ 8091 Zurich, Switzerland \\ e-mail: nicolas.mueller@usz.ch \\ Tel.: +41-1-2553712 \\ Fax: +41-1-2553291 \\ R. Jenni \\ Division of Cardiology, Department of Internal Medicine, \\ University Hospital, \\ Rämistrasse 100 \\ 8091 Zurich, Switzerland \\ R. Speich \\ Pulmonary Division, University Hospital, \\ Rämistrasse 100, \\ 8091 Zurich, Switzerland
}

PAHRH, the introduction of highly active antiretroviral therapy (HAART) has been found to improve right-sided heart pressure and mortality [3], and resolution of PAHRH has been described in some patients. It should be mentioned, however, that patients in these studies were often treated with both HAART and PAHRH treatment, making the specific contribution of each of these interventions difficult to differentiate. Furthermore, some studies have found an increased incidence of PAHRH in patients receiving HAART (reviewed in [4]). In the present report, we describe a patient with an atypical course of PAHRH in whom lipodystrophy necessitated interruption of HAART. During cessation of HAART, PAHRH remained stable, despite a rise in the patient's HIV viral load and a fall in his $\mathrm{CD}_{4}+$ cell count.

\section{Case report}

A 34-year-old male with a history of intravenous drug use was diagnosed with PAHRH 7 years after he had tested positive for HIV. The diagnosis of PAHRH was established after echocardiography to evaluate a rapidly progressing episode of dyspnea revealed a right ventricular systolic pressure of $59 \mathrm{mmHg}$ over right atrial pressure (RV/RA pressure gradient); the diagnosis was confirmed by invasive assessment. Secondary causes were excluded. The evolution and treatment of PAHRH and HIV in this case are shown in Table 1.

PAHRH stabilized under a therapy consisting of isosorbidinitrate, phenprocoumon and digoxin. At the time of PAHRH diagnosis, antiretroviral monotherapy with zidovudine (AZT) was started, with the subsequent addition of lamivudine (3TC). Three years later HAART was started with the addition of indinavir. Five years after PAHRH was diagnosed, clinical and echocardiographic signs of progression were noted, and an ACE inhibitor was added to the antibiotic regimen. A trial with the prostacyclin analogue iloprost (ilomedin; Schering, Baar, Switzerland) (inhalation, 3-5 times a day) led to marked clinical improvement but had to be stopped because it was 
Table 1 Diagnostic procedures, therapy, $\mathrm{CD}_{4}+$ cell count and viral load over time in a HIV-infected patient with pulmonary arterial hypertension

\begin{tabular}{|c|c|c|c|c|c|c|c|}
\hline \multirow{2}{*}{$\begin{array}{l}\text { Date } \\
(\mathrm{mm} / \mathrm{yy}) / \\
\text { diagnosis }\end{array}$} & \multicolumn{2}{|l|}{ Diagnostic tests } & \multirow{2}{*}{$\begin{array}{l}\text { Clinical } \\
\text { presentation }^{\mathrm{d}}\end{array}$} & \multicolumn{2}{|l|}{ Therapy } & \multicolumn{2}{|c|}{ Laboratory results } \\
\hline & $\mathrm{Echo}^{\mathrm{a}} / \mathrm{PAK}^{\mathrm{b}}$ & $\begin{array}{l}6 \text { min walking } \\
\text { test/Borg scale }\end{array}$ & & $\mathrm{PAH}$ & HIV & $\begin{array}{l}\text { CD4 } \\
\text { (cells/ul) }\end{array}$ & $\begin{array}{l}\text { Viral load } \\
\text { (copies } / \mathrm{ml} \text { ) }\end{array}$ \\
\hline \multicolumn{8}{|l|}{1987 HIV } \\
\hline 01/94 PAH & E: $59 / 32$ & & II & $\begin{array}{l}\text { phenprocoumon, digoxin } \\
(0.375 \mathrm{mg})\end{array}$ & AZT & 860 & nd \\
\hline $03 / 94$ & $\operatorname{PAK}(1)$ & & II & unchanged & AZT & & \\
\hline $09 / 95$ & $\mathrm{E}: 65 / 25$ & & & $\begin{array}{l}\text { same }+ \text { isosorbidinitrate } \\
\quad(40 \mathrm{mg})\end{array}$ & AZT, 3TC & 680 & nd \\
\hline 03/97 & & & & unchanged & 3TC, d4T, IDV & 650 & nd \\
\hline 03/99 & $\begin{array}{l}\text { E: } 75 / 32 ; \text { right } \\
\text { ventricle enlarged }\end{array}$ & & $\begin{array}{l}\text { III, edema } \\
\text { lower } \\
\text { extremities }\end{array}$ & $\begin{array}{l}\text { + lisinopril/ } \\
\text { hydrochlorothiazide }\end{array}$ & $\begin{array}{l}\text { 3TC, d4T, } \\
\text { efavirenz }\end{array}$ & 1769 & $\mathrm{n}$ \\
\hline $01 / 00$ & PAK (2) & $470 \mathrm{~m} / 2$ & & $\begin{array}{l}\text { +ilomedin }(5 \times / \text { d p.i. } \\
10 \mu \mathrm{g})\end{array}$ & $\begin{array}{l}\text { 3TC, } \mathrm{d} 4 \mathrm{~T}, \\
\text { nevirapine }\end{array}$ & nd & $\mathrm{n}$ \\
\hline $02 / 00$ & & $556 \mathrm{~m} / 2$ & & unchanged & unchanged & nd & $\mathrm{n}$ \\
\hline $05 / 00$ & & $633 \mathrm{~m} / 2$ & I-II & unchanged & unchanged & 1807 & $\mathrm{n}$ \\
\hline 07/00 & & $670 \mathrm{~m} / 2$ & I & ilomedin stop & unchanged & nd & $\mathrm{n}$ \\
\hline $01 / 01$ & E: not measurable $/ 20$ & & II & $\begin{array}{l}\text { phenprocoumon, digoxin, } \\
\text { lisinopril/ } \\
\text { hydrochlorothiazide }\end{array}$ & unchanged & nd & $\mathrm{n}$ \\
\hline $01 / 02$ & E: not measurable $/ 20$ & & II & unchanged & unchanged & 1231 & $\mathrm{n}$ \\
\hline $11 / 02$ & & $550 \mathrm{~m} / 4$ & II & unchanged & unchanged & nd & $\mathrm{n}$ \\
\hline $12 / 02$ & E: not measurable/24 & & II & unchanged & HAART stop & 1828 & $\mathrm{n}$ \\
\hline $01 / 03$ & & $570 \mathrm{~m} / 2$ & II & unchanged & unchanged & 1215 & 2235000 \\
\hline 03/03 & & $500 \mathrm{~m} / 2$ & II & unchanged & unchanged & 794 & 154500 \\
\hline $06 / 03$ & & $600 \mathrm{~m} / 2$ & II & unchanged & unchanged & 692 & 351000 \\
\hline 07/03 & E: not measurable/24 & & II & unchanged & $\begin{array}{l}\text { tenofovir, } \\
\text { nevirapine ddI }\end{array}$ & nd & nd \\
\hline 08/03 & & & II & unchanged & unchanged & 757 & 1080 \\
\hline $10 / 03$ & & & & unchanged & unchanged & 826 & 106 \\
\hline $01 / 04$ & E: not measurable/21 & $1050 \mathrm{~m} / 1$ & & unchanged & unchanged & 1097 & $\mathrm{n}$ \\
\hline
\end{tabular}

E, echocardiography; PAK, pulmonary artery catheter; PAH, pulmonary arterial hypertension; HIV, human immunodeficiency virus; AZT, zidovudine; 3TC, lamivudine; d4T, stavudine; IDV, indinavir; HAART, highly active antiretroviral therapy; ddI, didanosine; VL, viral load; nd, not done; $n$, not detectable

${ }^{a}$ First number $=$ right ventricular systolic pressure in $\mathrm{mmHg}$ over right atrial pressure in $\mathrm{mmHg}$; Second number $=$ right ventricular diastolic pressure in $\mathrm{mmHg}$ over right atrial pressure in $\mathrm{mmHg}$

b(1) Values 3/94: cardiac index 2.6 1/min, pulmonary resistance 625 dyne (no decrease of pulmonary resistance under infusion of prostin $450 \mathrm{ug} / \mathrm{h})$, median pulmonary arterial pressure $46 \mathrm{mmHg}$, wedge pressure $6 \mathrm{mmHg}$

(2) Values 1/00: before ilomedin: cardiac index $2.0 \mathrm{l} / \mathrm{min}$, pulmonary resistance 1126 dyne, median pulmonary arterial pressure $61 \mathrm{mmHg}$; after ilomedin: cardiac index $2.8 \mathrm{l} / \mathrm{min}$, pulmonary resistance 756 dyne, median pulmonary arterial pressure $56 \mathrm{mmHg}$

${ }^{\mathrm{c}}$ The Borg scale rates shortness of breath in a range from 0 to 10 whereby 0 indicates no shortness of breath at all while 10 indicates very, very severe shortness of breath

${ }^{\mathrm{d}}$ Clinical presentation was coded in accordance with the guidelines of the New York Heart Association whereby $\mathrm{I}=$ symptoms of heart failure only at levels that would limit normal individuals, II = symptoms of heart failure with ordinary exertion, III $=$ symptoms of heart failure on less than ordinary exertion, and IV = symptoms of heart failure at rest

causing persisting headaches. Phenprocoumon, digoxin, lisinopril/hydrochlorothiazide were continued, and PAHRH was noted to have stabilized clinically; this was confirmed by echocardiography.

At the time PAHRH first worsened (3/99), a significant exacerbation of the patient's lipodystrophy was noted under therapy with 3TC, stavudine (d4T), and indinavir. Indinavir was replaced by efavirenz and later by nevirapine. Lipodystrophy and, particularly, the buffalo hump pro- gressed further. The patient became severely handicapped, not being able to hold his head upright. Surgical therapy of the buffalo hump was considered but was felt to be too risky considering the PAHRH. Further testing revealed the patient's $\mathrm{CD}_{4}+$ cell count had risen to 1828 cells $/ \mu 1(54 \%)$ and his viral load was persistently non-detectable. On echocardiography, the systolic pulmonary arterial pressure gradient was no longer detectable, and diastolic pressure remained slightly elevated. Due to these excellent values 
and the progressing lipodystrophy, HAART was stopped with the consent of the patient. One month later the patient's viral load had risen to $>2 \times 10^{6}$ copies $/ \mathrm{ml}$ and the $\mathrm{CD}_{4}+$ cell count had fallen from 1882 to 1215 cells/ $\mu$ l. Dyspnea remained stable as did the echocardiography results.

The patient asked to resume HAART 7 months after it was stopped despite the fact that PAHRH had almost completely regressed and lipodystrophy had not worsened. HAART was restarted with tenofovir, nevirapine and didanosine. The viral load again became fully suppressed and the $\mathrm{CD}_{4}+$ cell count rose to 826 cells/ $\mu$ l. Eighteen months following re-initiation of HAART, PAHRH had not recurred, but the lipodystrophy still remained a problem.

\section{Discussion}

The pathogenesis of PAHRH is largely unknown, but HIVinduced cytokines, endothelin-1, human herpes virus 8 , or HIV-mediated autoimmune disease, among other factors, may play a role [3-6]. Prognosis of PAHRH is bad, with a median survival of 6 months after diagnosis. As with primary pulmonary hypertension, treatment options are limited. Newer agents such as bosentan and sildenafil [7-9] are under investigation. Given the potential role of HIV in the pathogenesis of PAHRH, the role of HAART has been examined. In a retrospective study on the role of anti-HIV treatment in PAHRH, HAART was found to be beneficial in terms of hemodynamic parameters and survival [10]. However, HAART alone did not always lead to an improvement of PAHRH, and in some studies it was associated with a higher incidence of PAHRH [4].

Several aspects of the case described here are noteworthy. In this patient PAHRH remained stable for over 5 years after its initial diagnosis and it regressed almost completely during the further course. Although antiretroviral therapy (initially AZT monotherapy, then AZT and 3TC) had been started at the time PAHRH was diagnosed, its impact is difficult to judge, since no viral load measurements are available from this time. While it is unlikely that the initial treatment resulted in complete viral suppression, it might have prevented a relevant loss of $\mathrm{CD}_{4}+$ cells, since all $\mathrm{CD}_{4}+$ cell counts were above $200 / \mathrm{ul}$. The length of the stable phase in this patient strongly contrasts with the short survival period previously reported for patients with PAHRH but without anti-HIV treatment. Intermittent deterioration of PAHRH in this patient occurred despite complete suppression of viral replication (documented for the first time 4 years after PAHRH diagnosis) and $\mathrm{CD}_{4}+$ cell counts $>1000$ cells/ $\mu$ l. Possible triggers for the sudden deterioration are not known. Inhalation therapy with ilomedin improved cardiac performance, but had to be stopped due to uncontrollable headaches. Due to the progression of severe lipodystrophy, HAART was interrupted; however, this decision was made reluctantly given the relatively long survival of the patient despite PAHRH and the potential role HAART might have played. Fortunately, no progression of PAHRH was noted after HAART was interrupted. It should be emphasized that PAHRH treatment was continued during the interruption of HAART, which at least questions the impact of HAART on the PAHRH.

Despite the favorable course reported here, close followup of patients with PAHRH is necessary to detect early signs of deterioration if HAART interruption is considered. Interruption of HAART should be reserved for cases in which no alternatives are available.

\section{References}

1. Speich R, Jenni R, Opravil M, Pfab M, Russi EW (1991) Primary pulmonary hypertension in HIV infection. Chest 100:12681271

2. Opravil M, Pechere M, Speich R, Joller-Jemelka HI, Jenni R, Russi EW, Hirschel B, Luthy R (1997) HIV-associated primary pulmonary hypertension. A case control study. Swiss HIV Cohort Study. Am J Respir Crit Care Med 155:990-995

3. Mehta NJ, Khan IA, Mehta RN, Sepkowitz DA (2000) HIVrelated pulmonary hypertension: analytic review of 131 cases. Chest 118:1133-1141

4. Pellicellii AM, D'Ambrosio C, Vizza CD, Borgia MC, Tanzi P, Pino P, Zachara E, Soccorsi F (2004) HIV-related pulmonary hypertension. From pathogenesis to clinical aspects. Acta Cardiol 59:323-330

5. Klings ES, Farber HW (2003) The pathogenesis of HIVassociated pulmonary hypertension. Adv Cardiol 40:71-82

6. Cool CD, Rai PR, Yeager ME, Hernandez-Saavedra D, Serls AE, Bull TM, Geraci MW, Brown KK, Routes JM, Tuder RM, Voelkel NF (2003) Expression of human herpesvirus 8 in primary pulmonary hypertension. N Engl J Med 349:1113-1122

7. Alp S, Schlottmann R, Bauer TT, Schmidt WE, Bastian A (2003) Long-time survival with HIV-related pulmonary arterial hypertension: a case report. Aids 17:1714-1715

8. Ricciardi MJ, Rubenfire M (1999) How to manage primary pulmonary hypertension. Giving hope to patients with a lifethreatening illness. Postgrad Med 105:45-48, 51-46

9. Sitbon O, Gressin V, Speich R, Macdonald PS, Opravil M, Cooper DA, Fourme T, Humbert M, Delfraissy JF, Simonneau G (2004) Bosentan for human immunodeficiency virus-associated pulmonary arterial hypertension. Am J Respir Crit Care Med 170:1212-1217

10. Zuber JP, Calmy A, Evison JM, Hasse B, Schiffer V, Wagels T, Nuesch R, Magenta L, Ledergerber B, Jenni R, Speich R, Opravil M (2004) Pulmonary arterial hypertension related to HIV infection: improved hemodynamics and survival associated with antiretroviral therapy. Clin Infect Dis 38:1178-1185 